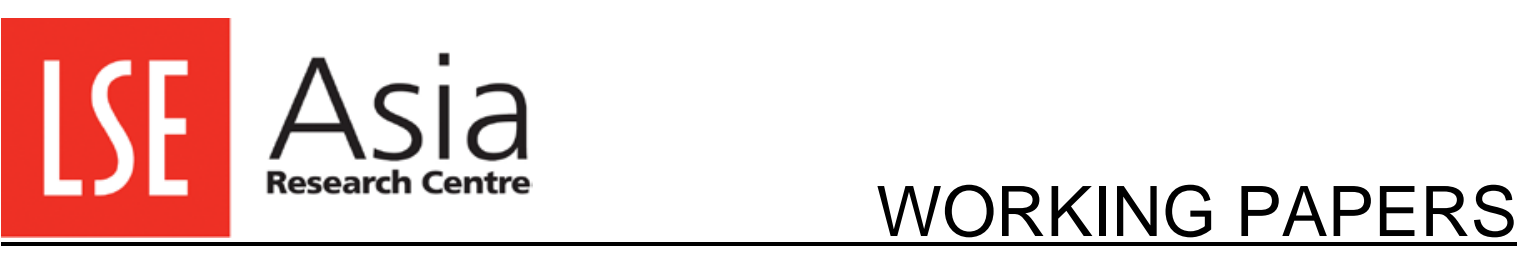

Governance and Institutions: The role of multilevel fiscal institutions in generating sustainable and inclusive growth

Ehtisham Ahmad 


\section{Governance and Institutions: The role of multi- level fiscal institutions in generating sustainable and inclusive growth}

\section{December 2013}

Dr Ehtisham Ahmad Visiting Senior Fellow, Asia Research Centre, LSE Email: s.e.ahmad@lse.ac.uk

All rights reserved. Apart from any fair dealing for the purpose of research or private study, or criticism or review, no part of this publication may be reproduced, stored in a retrieval system or transmitted in any form or by any means without the prior permission by the publisher or author (2013).

This paper is forthcoming in the Handbook of Multilevel Government Finance, Edward Elgar, 2014. Helpful discussion with Juan-Pablo Jimenez and comments from Farzana Ahmed, Teresa Ter-Minassian and Leif Jensen are gratefully acknowledged. The usual disclaimer applies.

For further information, please contact:

Asia Research Centre (ARC)

London School of Economics \& Political Science

Houghton Street

London

WC2A 2AE

United Kingdom

E-mail: $\underline{\operatorname{arc} @ I s e . a c . u k}$

www.Ise.ac.uk/asiaResearchCentre 


\section{Why institutions and Governance matter?}

Differences in political ideology might lead to different views about the role of the state in the provision of public services across countries, or even in the same country over time. ${ }^{2}$ At the same time, it is clear that effectiveness of institutions associated with the generation and use of public resources vary considerably across countries. Despite the nominal presence of institutions that resemble best practice, many countries have difficulties in effectively generating public resources and ensuring that the generated resources are not misappropriated or badly utilized. Political choices at each level of government matter, and incentives facing officials and politicians determine whether an appropriate environment is created for sustainable investment.

Institutions do not operate in a vacuum, and the context in which the organizational structure is established, may lead to very different results in Mexico as opposed to a similar structure in Brazil, or China. This is because incentives matter, and the balance of power and influence of elites, including bureaucracies, may determine whether or not an organizational structure generates rents at the behest of vested interests, especially in societies that North terms "limited access orders." Thus, attempts by international agencies to propagate "best practices" quite often fail.

Sustainable and inclusive growth in multi-level countries depends on creating the right incentive structures for public and private investments, and supporting public service delivery at each level of government. Many of the organizations are the same across the world, and constitute budgetary and revenue agency functions encompassing the sources and uses of funds. However, the context matters, and the wider set of incentives facing officials and politicians often result in different institutional arrangements (North, 1990).

This paper focuses on the incentives facing politicians and officials to use public resources efficiently-both their own and from donor agencies, as well as those provided by higher levels of government in the case of sub-national entities. As the recent crisis in Europe has shown, weaknesses in institutions and information flows affect the incentives facing subnational governments and associated central and subnational entities. This has resulted in unsustainable and unproductive investments, leading to a collapse in the overall macroeconomic framework in

2 This is sharply seen in the case of the United States and the differences in world view between Republicans and Democrats. 
countries from Ireland to Portugal, Spain, Italy and Greece-and indeed similar influences were at play in the Latin American and Asian crises in the 1990s. The focus had become to attract funds from higher levels, or capital markets, to the detriment of accountability to the relevant electorates, or effectiveness of provision.

Public financial management (PFM), somewhat narrowly defined, in terms of processes and organizations, including budget preparation and execution, audit, accounting and reporting, was recognized by international agencies as being relevant for decentralized operations (Ter-Minassian 1997). However, the more recent literature on the political economy of multi-level governance (see Ahmad and Brosio, 2006) places the design of institutions and associated flow of information at the heart the structure of incentives that underpin the public policy debate.

In this paper, we recast the old PFM discussion into a broader policy context of determining questions such as "Who does what to generate sustainable growth? How these activities are financed? What is the balance between taxation and various instruments to spread financing costs over a reasonable period, and the measures to mitigate risks of default? Where does the money flow? And what are the effects and outcomes of the spending? The wider institutional arrangements governing these questions and issues become the focus of the policy choices. The asymmetric flow of information poses problems, and affects the incentives for central or local officials to play games with other levels or donors, or to misappropriate resources. The design and incentive structures have immediate implications for the sustainability of the growth process.

The context matters, and nominally similar organizational structures (see North 1990) may generate very different results or outcomes in different countries. We focus in this paper on the need for tighter standards on the flow and availability of information on the sources and uses of funds. Some of the associated institutional requirements are also discussed. However, it is increasingly recognized that the design and financing of public policy are very closely interrelated and it is a mistake to treat the issues completely separately (Ahmad and Best, 2012).

In Section I we set the stage for sustainable growth, examining the global need for investment, given limited public resources. The availability of resources in certain parts of the world, e.g., the sovereign wealth funds, seeking assured returns, suggests the need for intermediation-including by long-term instruments, as emphasized by the G30 report, together with risk mitigation, e.g., by multilateral agencies. However, to the extent that national governments are involved, e.g., through public private partnerships, this also puts a premium on the recognition of public liabilities in the medium-to-long term, and need for effective tax policies. Throughout, the nexus between policy and institutional arrangements remains critical. 
In Section II we examine issues related to accountability at different levels of government-these are inexorably linked to the policy decisions of who does what. Again, both policies and institutional arrangements are intertwined.

Section III relates to the second ingredient of incentives and accountability-linked to whether or not sub-national entities have access to own-source revenues. This makes it easier to link responsibilities to outcomes, and the presence of own-source revenues facilitates the implementation of hard budget constraints.

Incentive issues are also associated with the efficient design of tax policies and associated administrations. The development of wide-base and interlinked taxes, particularly the income taxes and the VAT provides a potential to finance critical spending on the social sectors that is critical for growth, as well as operations and maintenance for investment. This also highlights the need for cross-jurisdictional tax administrations-particularly at the central or federal levels. Split tax bases could be addressed by complicated and overlapping tax administrations. There may also be a possibility for the establishment of independent revenue agencies, which could service the central and intermediate tiers of government-on an agency model (like central banks). The political acceptability of this option may need to be explored, and considerable work is needed in this regard, especially in Latin America, but also in Asia.

For more typical local tax assignments, the administrative issues are less problematic. These could be seen as a continuum linked to capacities. Different administrative functions could be tailored for specific contexts with possibilities of asymmetric arrangements, especially for large metropolitan areas.

In Section IV we focus on selected issues relating to the management of the spending process at each level of government. The key issue governing accountability is the timely, standardized and consistent flow of information on who spends what and the results of the process. We focus on minimizing the incentives to "play games" in multi-level countries and common markets/currency unions. There are benefits from the use of the full GFS2001 framework, as well as an efficient following of the cash. We also address the special case of "kicking the can down the road," now being seen with public-private-partnerships, including in the most advanced countries, and measures to minimize the build-up of public liabilities.

Section V examines transfer design. Earmarked and gap-filling transfers can completely offset the positive incentive effects of own-source revenues and efficient expenditure management institutions. We make the case for equalization transfer systems-almost completely absent from Latin America, and apart from China, not extensively used in Asia. We also put in context the case of performance-based transfers, which are increasingly popular with donors and international agencies. As with other popular measures, the preconditions for making these measures work effectively are poorly understood. 


\section{Sustainable Growth—an enabling policy framework}

Sustainable growth in developing countries requires significant resources to meet infrastructure gaps, and equally for building human capital, providing productive employment opportunities, and mitigating risks facing households. These are not competing objectives, but rather reflect complementarities for achieving high quality and sustainable growth.

It is unlikely that tax revenues in the short to medium term will be sufficient to cover the magnitude of investment needed, and there is a good case to be made for public borrowing for investment-to facilitate private sector investment. Given excess savings in some parts of the world, and considerable investment needs elsewhere with relatively high social and economic rates of return, risk mitigating intermediation is likely to be increasingly important. Additionally, sound macroeconomic policies are essential in providing an enabling environment, conducive to sustainable growth.

While the recent G30 report correctly placed emphasis on the private sector, longer maturity investments are unlikely to take place without significant risk mitigation. This may involve both national governments and an increasing role for cross-border risk mitigation by existing multilateral agencies (such as CAF in Latin America) or a new BRIC Bank representing regions with excess investible resources in search of assured returns. While the G30 report downplays the role of the public sector, given the need for fiscal consolidation in many parts of the world, the suggested solution for reliance on public private partnerships does not provide a mechanism to avoid domestic resource mobilization. Indeed, the disincentives involved in PPPs without clear delineation of responsibilities have been the cause for many of the current difficulties faced in different parts of the world, as the can gets kicked down the road.

As we discuss below in Section III, steps are being taken globally to recognize the public in PPPs, and tighter accounting rules are being proposed to prevent the can being kicked down the road. The key issue relates to the time horizon over which the liabilities are recognized. This provides a time frame within which domestic resource mobilization in specific countries must be cast. China presents a very interesting case of the interlinkages between structural change and tax reformsthe transformation initiated in the late 1970s had to be buttressed by major tax reforms in the early 1990s. This provided the basis for the sustained growth over the following two decades. And now, tax reforms are forming the basis for the subsequent structural change over the coming decade (see Ahmad, Rydge and Stern, 2013). 
Tax revenues should be related to a clearly defined role for the state, including provision of public services (for general government), as well as public responsibilities for investment and infrastructure-within a medium-term framework. As described in Ahmad and Stern (1991), the structure of taxes should reflect considerations of productive efficiency, distributional considerations, as well as administrative feasibility. In principle, combinations of tax instruments could be used to meet distributional considerations-e.g., a single rate VAT could be used in conjunction with selective excises to generate overall progressivity in the indirect tax system-and the concern for the poorest could be met through targeted transfers. As described in Ahmad, Best and Pöschl (2012), "holes" in the tax system designed to meet distributional concerns, or to encourage specific industries, eventually degenerate into shelters for "cheating", and often fail to generate revenues or meet the stated objectives as well.

Tax instruments can also affect demand and supply responses to reduce carbon emissions or consumption of bads, and provide financing for compensatory measures if needed. This would be a key element of a desirable overall tax structure, reflecting government preferences in multilevel administrations.

The key role of tax policy in supporting investment and structural change lies in the creation of a level playing field-as opposed to incentives and "holes". Further, access to own-source revenues at the subnational level is essential to provide incentives for responsibility and efficiency. Overall, the level of tax revenues has to be commensurate with the buildup of reserves to meet current and future liabilities in a sustainable manner. Indeed, the extent to which the public sector can gear additional resources for investment depends on the feasible revenue-envelope in the medium-term. National and subnational fiscal rules need to be devised accordingly (Ter-Minassian, forthcoming).

In the sections to follow, we examine the issues of which level of government should do which function to enhance growth prospects. In each case, the ways in which the spending is financed influences the effectiveness of the spending, and incentives for accountability.

\section{Spending and accountability}

It is critical for public spending to be clearly defined, accountable and linked to financing and build up of liabilities. Many large-scale investment projects that facilitate the operation of the private sector are in the domain of the central government, or even at the supranational level (in the EU with structural policies; or the CAF financing cross-border infrastructure in Latin America).

Trends towards decentralization are evident in both OECD and developing countries. But evidence on the supposed links between the decentralization process 
and the generation of growth remain tenuous at best (Ahmad, Brosio and Tanzi, 2008). This puts much greater emphasis on the incentive compatible design of decentralization process in order to achieve the growth potential that undoubtedly exists.

Countries decentralize for many reasons, and often the political dimensions dominate the purely technocratic, normative assignments. This often has to do more with satisfying disparate groups and keeping the country together than arguments related to efficiency in the provision of public services as well as to engender sustainable growth. ${ }^{3}$ However, whatever the motivation governing the degree and sequencing of decentralization, public policy has to be concerned with overall welfare, especially that of the marginalized and poorer sections of society, the effectiveness with which public services are delivered, and the scope for sustainable growth. This paper takes a "political economy" perspective in relation to the institutions needed for the effective provision of public services at the subnational level., and particularly the responsibility for investment needs, where the benefits and costs may be spread across jurisdictions as well as over time (hence spanning the tenure of most sub-national governments)

A useful typology of spending responsibilities and how different countries approach the issues is given in Chart 1 that addresses the subsidiarity principle. This states that assignments should be devolved to the lowest level capable of effectively providing them. This is a general principle of the EU legal framework, constraining the supranational level from legislation to areas where action at the national, regional or local levels is insufficient. ${ }^{4}$ The concept has both legal and political ramifications. The focus is on scale as well as effects, including externalities, on other jurisdictions, and this has given rise to actionable cases where there is a legal connotation, as in the EU. ${ }^{5}$ In political terms, the concept of subsidiarity is often taken beyond the multi-level government connotation to also include the boundaries between the private sector and the role of the state (at any level).The presumption, especially be conservative commentators in the US, is that as far as possible the private sector should be encouraged to provide public services, as this is expected to be more efficient than public provision.

Chart 1 shows the differing trends regarding the centralization/ decentralization debate in different countries or regions. The arguments for decentralization of functions are based largely on accountability and effective provision, given the subsidiarity principles. But it is not enough to legislate the assignments-the lower

${ }^{3}$ Despite the expectation, the linkages between decentralization and growth are somewhat tenuous, and are surveyed in Ahmad and Brosio (2009).

${ }^{4}$ See http://eur-lex.europa.eu/en/treaties/dat/12002E/pdf/12002E_EN.pdf.

${ }^{5}$ An interesting example is the European Court of Justice's rejection of a case brought by the German Government against an EU Directive on Deposit Guarantee Schemes (Case C-233/94). 
levels have to have the capabilities as well as the incentives to provide the services. Both these are linked closely to the financing issue, as well as incentives for effective provision. Thus, arguments that local governments lack "capacity" are not strictly binding if they have the financial resources to hire skilled workers.

Chart 1

\section{Modified subsidiarity principles}

Centralization
needs
- Cooperation
- Coordination
- Harmonization
Factors
- Economies of
scale
- Spillovers
- Congestion
Political
economy
- Equalization
- Interpersonal
equity

Centralization

- Harmonization

Factors

Economies of

Spillovers

Political economy

- Equalization equity

Adapted from Dafflon, in Ahmad and Brosio, Handbook of Fiscal Federalism

\section{Decentralization}

- Devolution

- Participatory democracy

- Control

- Accountability and effective provision

Political economy

- Yardstick competition

\section{Local}

Financing at margin

Accountability
National/federal

- Financing

Provincial

Financing at margin

Accountability
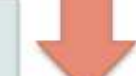

(1) 
Offsetting the decentralization trends are concern that limit subsidiarity-mainly externalities such as spillovers (including with environmental considerations), congestion and economies of scale. Moreover, decentralization especially of resource bases could exacerbate inequalities across regions and also limit the extent of interpersonal redistribution that might be feasible. In all cases, there is a role for the Federal, Central or Supranational agencies to coordinate and harmonize essential policies. In the United States and some other federations, the maintenance of a unified economic space has been facilitated through a "commerce clause." In the EU, a common economic space is ensured through the common external tariff and harmonization of the country-level VATs (see the EU Sixth Directive) to minimize harmful competition. Thus, a combination of legal and regulatory frameworks is essential to ensure equality of treatment and opportunity. Again, for this to work efficiently, full information is needed on who spends what, and the buildup of assets and liabilities, and as the recent EU experience illustrates, inadequate attention to the standardized flow of information could jeopardize a common economic space.

Developing countries have tended to take either a gradual approach to decentralization-focusing on capacities and relying heavily on overlapping functional responsibilities (especially in Latin America-such as in Bolivia and Peru). ${ }^{7}$ While this may prevent "wasteful spending", it does not guarantee that the local governments will take responsibility for functions or sub-functions, such as primary education. This is because they are not responsible for the full function, and for important economic components (such as wages or full operations and maintenance-see Section 2 below). Especially in the face of weak information systems (Brazil is an exception in Latin America-and Mexico is the other end of the spectrum $),{ }^{8}$ the prospect of holding local governments responsible for any public function is tenuous at best-limiting the role that yardstick competition may play to improve spending outcomes.

At the other extreme, some countries (especially in Asia-Indonesia a decade ago, and Pakistan in 2010) have adopted a "big-bang" approach, with a rapid devolution of functions. In the Indonesian case, this was from the center to the third tier-or districts--largely to prevent adding to centrifugal pressures that had been present in a large and diverse country. While the devolution was accompanied by a new revenue-sharing, the incentive structures were distorted by the design of transfers that encouraged the creation of new jurisdictions more than the effective provision of public services. Discontent with the level of public service provision has led to the gradual devolution of own-source revenues (through the property tax), as well as a new set of service delivery norms.

${ }^{7}$ See Ahmad and García-Escribano (2011).

${ }^{8}$ Mexican Ministry of Finance and Public Credit and IMF, FAD 2007--Ahmad et al. 
While simple norms can work to galvanize local opinion by providing standards to judge local government performance, these have to be accompanied by transfer design that do not distort incentives, as well as much freer flow of information on service delivery spending and outcomes in relevant neighboring jurisdictions. In the Indonesian case, there is considerable work to be done to coordinate and standardize information generated at the local level, and by the Ministries of Home Affairs and Finance (none of these sources agree on the details of local spending). Moreover, very detailed norms (that resemble GOSPLAN) may actually be unimplementable given the very limited information flows that are available at the present time.

In Pakistan, the Musharraf devolution at around the same time as Indonesia was also to the districts, but unlike Indonesia, neither functions nor financing was made clear. This was more a way of avoiding the provinces, which were also centers of civilian political power. This devolution was reversed with the return to democratic rule in 2008, and a new constitutional amendment (18 ${ }^{\text {th }}$ Amendment) devolved full functions to provinces in 2010. However, inadequate attention was paid to either financing or implementation capacities-and many of the functions appear to have become unfunded mandates with a continuing deterioration in the standards of public service delivery and outcomes. At the macroeconomic level, the failure of national tax reforms has led the federal government to borrow from the banking system, effectively crowding out of investment and the private sector. This has led to a build up of general government liabilities-with no financing for any level of government and a fall in the growth potential to a very low level that leads to a stagnation of real income levels.

In the Chinese case-local investment opportunities together with the responsibility system led to a growth stimulus. This was sustained by a major tax reform in 1994, predicated on creating a State Administration of Taxation, and the implementation of central and shared taxes-principally the VAT. This has led to an accumulation of reserves for investment. Additional tax reforms are now needed in order to direct investment and consumption, and to generate greater local accountability (Ahmad and Stern, forthcoming).

As the diverse examples above show, there are no perfect solutions to the issue of accountability and ensuring improved service delivery or investment enhancement. It is however clear that critical ingredients in getting better outcomes, whether in "deconcentrated settings", or in fully decentralized environments, are to generate "standardized information on who spends what and what are the outcomes in terms of spending as well as resulting assets and liabilities. 


\section{Sub-national Revenue Assignments, Management and Accountability}

The links between policy and management and incentive structures is clearly illustrated in the case of national and subnational revenues. Own-source revenues at the margin are recognized as critical in establishing incentives for subnational governments to effectively provide services and manage spending efficiently (Ambrosiano and Bordignon. 2006). Own-source revenues are also critical in establishing hard-budget constraints, as without own-source revenues the ability to repay debt incurred becomes questionable.

As described in Ahmad and Brosio (2009a), Latin American countries generally do not have adequate own-source revenues at the regional or intermediate level. Brazil's sub-national VAT is an exception, however, it causes distortions, problems with trade facilitation and encourages "cheating." In most countries the centralizing effect of the VAT is apparent, and revenue-shares do not constitute own-source revenues in a strict sense, and operate like transfers as local governments do not have control over rate structures or the base of the tax (see Table 1, columns 1a and $1 \mathrm{~b}$ ). The revenue-shares are, however, critical in meeting the vertical imbalances; and alternatives need to be sought that do not involve the complexity of both the policy framework as well as difficulties with administration. Indeed, the two are clearly linked.

Splitting the revenue base for the major taxes-such as the ISR (Income taxes) and VAT in Mexico, with firms under $2 \mathrm{~m}$ pesos being administered by the states under the small taxpayer (REPECOS) regime, creates an additional loophole that further adds to the incentives to informality and cheating in Mexico, ${ }^{9}$ leading to a non-oil tax/GDP ratio of around 10\%. States have little incentive or capability of auditing REPECOS companies, most of which are bunched at the bottom end-suggesting that they pay just enough to satisfy the states and to keep the Federal SAT off their backs (Ahmad, Best and Pöschl, 2013).

Consolidating the ISR as well as the VAT, and creating a new business tax at the local level may be a possible solution. For the States, in principle, a piggy-back or surcharge on the income tax, and a Canadian-style dual VAT, could both provide them with own-source revenues without the need to establish a separate tax administration (see Columns $2 \mathrm{a}$ and $2 \mathrm{~b}$ in Table 1). One could think of a continuum of tax policy/administration functions that could be gradually devolved to

${ }^{9}$ It is estimated that evasion from the REPECOS is around 95\% (SAT, 2011); and this creates additional incentives for firms to hide their transactions. 
subnational governments, depending on the policy framework and capacity to administer (see Table 1).

There is also an important political economy element in the choices, as subnational governments may not trust a national or federal revenue administration-which are becoming more common in Latin America (see Table 2). The political economy difficulties may be reduced if the revenue administrations are converted into Independent boards, like Central Banks, but with representation from states and subnational governments on the Boards. This, however, also faces formidable political economy constraints in specific countries and would have to be very carefully discussed with various levels of government in order to achieve a buy-in.

Table 1.

\section{Typology for local taxation and policy}

\begin{tabular}{|c|c|c|c|c|c|c|c|c|}
\hline \multirow[b]{3}{*}{ Key Factors } & & $1 \mathrm{a}$ & $1 \mathrm{~b}$ & $2 a$ & $2 b$ & 1 & $3 a$ & $3 b$ \\
\hline & \multirow{2}{*}{$\begin{array}{c}\text { Central } \\
\text { Tax }\end{array}$} & \multicolumn{2}{|c|}{ Shared taxes } & \multirow{2}{*}{\multicolumn{2}{|c|}{$\begin{array}{c}\text { Own-revenue/ } \\
\text { Surcharge } \\
\text { Joint- } \quad \text { Central }\end{array}$}} & $!$ & \multicolumn{2}{|c|}{ Local Tax } \\
\hline & & $\begin{array}{l}\text { Central } \\
\text { Admin }\end{array}$ & $\begin{array}{l}\text { Joint- } \\
\text { Admin }\end{array}$ & & & ! & $\begin{array}{l}\text { Joint- } \\
\text { Admin }\end{array}$ & $\begin{array}{l}\text { Local } \\
\text { Admin }\end{array}$ \\
\hline $\begin{array}{l}\text { Rate/ } \\
\text { base }\end{array}$ & CG & CG & CG & LG & LG & $!$ & LG & LG \\
\hline & & i $\mathbf{C G} /$ & CG / & & & ! & & \\
\hline Revenue & CG & LG & LG & LG & LG & $!$ & LG & LG \\
\hline ADMIN & & ! & & & & i & & \\
\hline Registration & CG & CG & CG & CG & CG & ! & LG & LG \\
\hline Valuation & $\mathrm{CG}$ & CG & CG & CG & CG & $!$ & LG & LG \\
\hline Assessment & CG & CG & CG & CG & CG & $!$ & LG & LG \\
\hline Bill Delivery & CG & CG & $\begin{array}{ll}\mathrm{Eg} \\
\mathrm{IG}\end{array}$ & If & CG & I & LG & LG \\
\hline Collection & CG & CG & CG & $\mathrm{CG}$ & CG & $!$ & LG & LG \\
\hline Enforcement & CG & CG & CG & CG & CG & 1 & LG & LG \\
\hline Services & CG & CG & $\mathrm{LG}_{\mathrm{fg}}$ & LG & CG & ! & LG & LG \\
\hline & & & & & & & $\mathrm{Au}$ & \\
\hline
\end{tabular}


Table 2

\begin{tabular}{|c|c|c|c|c|c|c|}
\hline & Argentina & Canada & Mauritias & Peru & Singupere & Spain \\
\hline Law & $\begin{array}{l}\text { Rxecutive Decree } \\
115606 \\
\text { (1996/rev.1997) }\end{array}$ & $\begin{array}{l}\text { Canada Customs and } \\
\text { Revenue Agency Act } \\
\text { (1999/rev 2004) }\end{array}$ & $\begin{array}{l}\text { Maunitis } \\
\text { Revenue } \\
\text { Authority Act } \\
2004 \text { (prev. } \\
\text { Unified Revenue } \\
\text { Authorify Act) }\end{array}$ & $\begin{array}{l}\text { Eubling Law } \\
24449 \text { (Decree } 501 \text {. } \\
\text { rev } 2002 \text { ) }\end{array}$ & $\begin{array}{l}\text { Inland Revenue } \\
\text { Authority Act (1992/rev } \\
2005)\end{array}$ & $\begin{array}{l}\text { 103; State Tax } \\
\text { Administration Agency } \\
\text { Law 31-1990 }\end{array}$ \\
\hline Mandate & $\begin{array}{l}\text { Tax and Customs and } \\
\text { Social Security }\end{array}$ & $\begin{array}{l}\text { Administration and } \\
\text { enforcement of } \\
\text { pertinent legislation }\end{array}$ & $\begin{array}{l}\text { Assessment and } \\
\text { collection of } \\
\text { taxes, } \\
\text { enforcement of } \\
\text { revenue laws }\end{array}$ & $\begin{array}{l}\text { Manage, asdit, } \\
\text { collect taxes, } \\
\text { regulate } \\
\text { international trade in } \\
\text { goosls }\end{array}$ & $\begin{array}{l}\text { Administer, assess, } \\
\text { collect and enforce } \\
\text { payment of taxes }\end{array}$ & $\begin{array}{l}\text { Tax and customs } \\
\text { systems }\end{array}$ \\
\hline $\begin{array}{l}\operatorname{limk} t o \\
\operatorname{MOF}\end{array}$ & $\begin{array}{l}\text { Reports to Minister for } \\
\text { general supervision } \\
\text { and legal control }\end{array}$ & Separate Minister & $\begin{array}{l}\text { Oversight and } \\
\text { final } \\
\text { responsibility }\end{array}$ & $\begin{array}{l}\text { Minister of Finunce } \\
\text { appoints head }\end{array}$ & General accouniability & Attached to MOF \\
\hline $\begin{array}{l}\text { Public } \\
\text { Service }\end{array}$ & Outside & Outside & Outside & Outside & Outside & $\begin{array}{l}\text { Public service rules } \\
\text { (limited autonomy) }\end{array}$ \\
\hline $\begin{array}{l}\text { UR } \\
\text { Aistonowy }\end{array}$ & Yes & Yes & Yen & Yes & Yes & Limited \\
\hline Funding & $\begin{array}{l}2.75 \% \text { of collection } \\
\text { formula, must comply } \\
\text { with government } \\
\text { accounting, asset } \\
\text { management, and } \\
\text { procurement } \\
\text { regulations }\end{array}$ & $\begin{array}{l}\text { Normal budget } \\
\text { appropriations- must } \\
\text { comply with } \\
\text { government } \\
\text { accounting, ascel } \\
\text { management, and } \\
\text { procurement } \\
\text { regulatioes }\end{array}$ & $\begin{array}{l}\text { Normal budget } \\
\text { and } \\
\text { parliamentary } \\
\text { approgriations }\end{array}$ & $\begin{array}{l}2.5 \% \text { of import } \\
\text { tariffs; } 2 \% \text { of other } \\
\text { tax collections: } \\
\text { follows public } \\
\text { sector procurement } \\
\text { asd financial } \\
\text { policies }\end{array}$ & $\begin{array}{l}\text { \% of expected rovenues; } \\
\text { plus incentives penalties; } \\
\text { civil service financial } \\
\text { rules including } \\
\text { procurement }\end{array}$ & $\begin{array}{l}\text { Normal appropriations } \\
\text { plus retention of } \% \text { of } \\
\text { revenue collected: } \\
\text { follows publie sector } \\
\text { procurement and } \\
\text { financial policies }\end{array}$ \\
\hline
\end{tabular}


The situation is better at the municipal level, where the property tax is correctly recognized as being important in many countries-although it is not strictly a local tax in many others (with the regions/states having an important role in countries like Mexico and Bolivia in setting rates and other elements of the administration matrix-see Table 1).

From the perspective of local accountability and responsibility, having own-source revenues is critical. As we have seen above, the capacity constraints need not be binding, and international agencies like CEPAL/IADB could assist with the work towards making revenue agencies truly independent, and encouraging piggy-backed options at the states/departmental levels; and developing business and property taxes at the local level, again using the principles of modern tax administration relying on self assessment, accurate flow of information on transactions and valuations. The use of third party information, as is being developed in South Asia, might be another area where loopholes and incentives for informality might be "closed."

Asymmetric arrangements are needed for large metropolitan areas, such as in the case of Mexico City or Bogotá, Beijing or Shanghai, which operate as states/provinces, as well as local governments. These are often the main engines of growth, and the proper institutional structures and incentives are needed to achieve the most efficient outcomes.

Creating own-source revenue handles is a first step. Ensuring that states and local governments have the incentives to use them depends on the design of the transfer system. If transfers are designed to meet deficits and gaps, there will be no incentive to use own-source revenue handles and manage spending efficiently. 


\section{Expenditure Management and Accountability}

The main issue from the perspective of implementing appropriate institutions for the management of public funds is to ensure that there are incentives to make local governments accountable to local electorates. Also, there should be responsibility for funds received from the center/supranational agencies and donors; and the use of credit should be managed in a transparent and sustainable manner. This involves more than a mere transplant of organizational structures from developed countries, but also to ensure that these are used effectively. Thus, the process is much broader than a ticking off of boxes in a PEFA matrix, much emphasized by the BrettonWoods Institutions, but addressing the incentives for and ability to "play games."

It is clear that poor information flows reduce local accountability, negate yardstick competition, and also facilitate game-play vis a vis the central or supranational/ international agencies. The game-play has been clearly highlighted in the case of the EU and incentives for autonomous agencies as well as regional and local governments to "hide" information or "kick the can down the road." Limited information flows also facilitate rent-seeking and diversion of resources.

Relatively few countries in Latin America or Asia utilize, for both the central as well as the subnational governments, the full format of the IMF's Government Financial Statistics Manual 2001 (GFSM2001) - which is designed to ensure conformity of the financial information with the System of National Accounts. ${ }^{10}$ Multiple formats in Mexico at the Federal level and across the states make it difficult to generate standardized information for general government. This makes it problematic to ensure comparability across subnational entities or engender accountable competition across states. Brazilian states, while not conforming to the GFSM2001, perform better than Mexico in that the Federation requires a standardized format to receive, report and report on Federal resources as well as their own resources.

Without a complete a complete and standardized format to categorize the cycle of revenues and expenses; in conjunction with a tracking of the cash flows; the likelihood of "game-play" by various levels of government or government agencies cannot be ruled out. A typical problem is the inconsistent treatment of budget

${ }^{10} \mathrm{~A}$ number of countries use transition matrices for the reporting of central or general government information to the IMF in the GFSM2001 format. Pakistan for example reports data only for the budgetary central government in the latest issue of the GFS Manual. This is inadequate, as much of the social spending takes place at the subnational level. 
coverage-with the frequent exclusion of spending of government agencies or liabilities parked in public enterprises.

In the very simple example of chart 2, the cash transactions of a government are shown as set $\mathrm{C}$. This is a subset of $\mathrm{F}$, which also includes financial assets and liabilities. In turn, $\mathrm{F}$ can be denoted as a sub-set of $\mathrm{R}$, which also includes all currently assets and liabilities. It is relatively simple for governments to reduce deficits in cash (C) or financial assets (F), without affecting all recognized liabilities (R) or extended net worth based on future flows (E). For instance, (sub-national or national) governments could engage in game-play, by

- Selling non-financial assets in R, for cash in F;

- Assuming future pension liabilities in E, for cash and financial assets in F;

- Securitization C of future revenue streams F (common in Latin American local governments;

- Treating borrowing $\mathrm{F}$ as revenue C (several US States).

Chart 2

\section{Rights and obligations associated with all future cash flows, E}

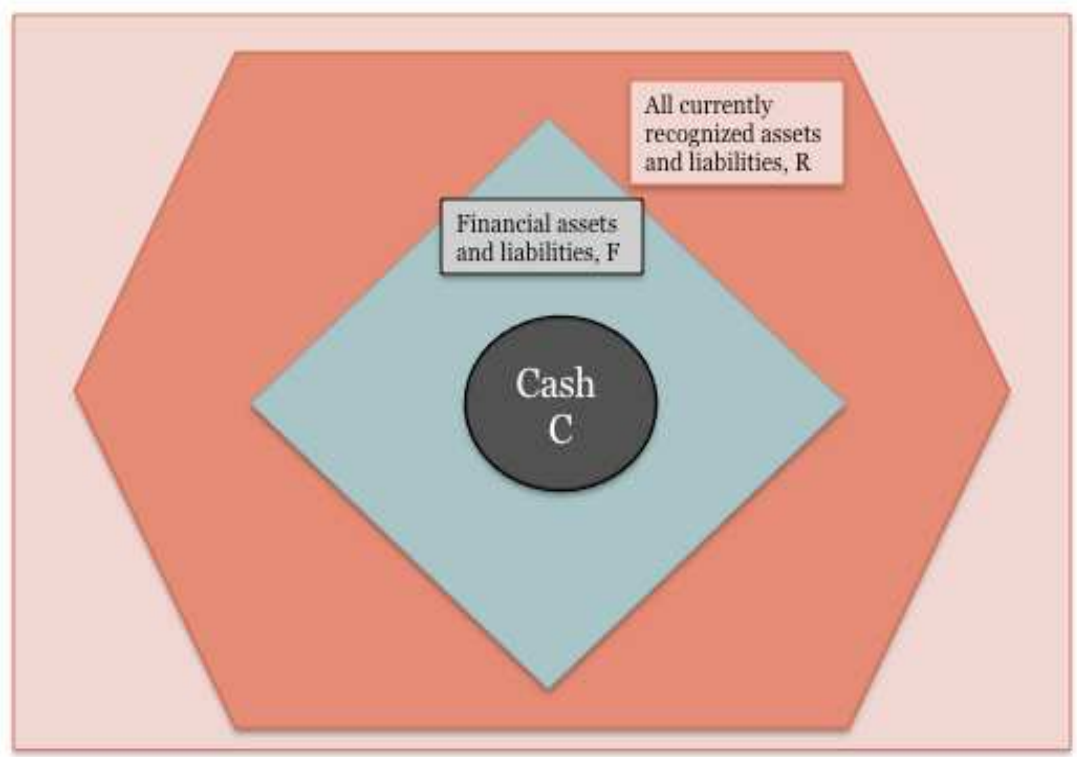


The sets C, F and R are consistent with the IMF GFSM2001. These represent nested sets of information, and if presented in parallel with E, virtually removes the scope for game-play by governments at any level.

Standardized information is critical for any serious implementation of fiscal rules in multi-level countries/currency unions. This should be based on the consistent and systematic generation of information in the overlapping manner described above.

There is a growing popularity of performance budgeting at the center (in both Latin American and Asian countries, including Mexico and Pakistan), as well as participatory budgeting at the local levels. Often bilateral donors, seeking to improve budgetary outcomes, drive this tendency. It is clear that focusing on outcomes is a useful addition to a regular budget process, but does not eliminate the need for a consistent, standardized and timely flow of information, so that electorates and policy makers are able to judge the true costs of their policy choices.

The importance of the GFSM2001 cannot be over-stressed, not for reporting to the IMF, but for the efficient management of finances in multi-level countries and in common markets/currency unions. This has implications for the assistance that could be provided by CEPAL, the IADB and the BWIs to member countriesstressing the importance of a consistent chart-of-accounts for each subnational government consistent with GFSM2001. This will involve changes to the GFMISs at the national and subnational level being implemented in countries like Peru, Bolivia and Indonesia. This also has implications for Brazil, as it seeks to upgrade its very successful SIAFI dating from the 1990s; and for countries in the EU (such as Portugal and Spain) as they struggle to get to grips with the discovery of liabilities in the extended public sector as well as at the regional and subnational levels.

\section{PPPs-kicking the can down the road?}

PPPs have been encouraged, including by international finance agencies, as a means of leveraging "private sector" expertise for public investment project, and also bypassing bureaucratic bottlenecks. This is believed to generate efficiencies, and improved value for money, especially at the subnational level. The expectation is that this will generate additional growth through the efficiencies and additional private finances that would be utilized.

The problem is that governments, especially although not exclusively at the subnational level; see PPPs as a means of circumventing budget constraints. This could generate legal obfuscations, and relevant official agencies or governments are either not fully aware of the liabilities, or the ability of the private partner to meet them. Sometimes, the issue of liability for full costs is avoided, often with respect to public infrastructure (highways and hospitals in Europe); and local governments only include the annual contractual cash payment on the budget, and generally only 
during the tenure of the concerned local government. Often, there is no provisioning for the eventual reversion of the assets to the public sector. Further, there is usually a continuation of public interventions with respect to prices or distribution.

There is also incomplete and asymmetric information, with costs and efforts for projects generally known only to the private partner, and significant incentives for either the private contractor or the government to renege (Danau and Vinella, 2012). An example of a growing recognition of limited commitment comes from the UK (which was in the forefront of the PPP revolution). In the 2002-3 upgrading of the London Underground, Metronet the contracting consortium could not borrow the full amount of funds needed for the project. Consequently, Transport for London, the decentralized agency responsible guaranteed 95\% of Metronet's debt obligations. Metronet failed, and the UK Government (Department of Transport) had to pay Transport for London a sum of $£ 1.7$ billion to enable it to meet the guarantee (House of Lords, 2010). The direct cost to taxpayers was estimated to be as high as $£ 410$ million. Other examples from the UK, e.g., for wind farm projects, show that in these cases the private contribution was financed by complex financial instruments that are tantamount to debt-that has eventually to be taken over by the state.

As a result of the difficulties above, the International Accounting Standards Board (2011) has issued a new set of guidelines (IPSAS 32) ${ }^{11}$ that force an upfront accounting for PPPs, and would significantly affect deficits and recognition of liabilities for general government-i.e., for both central and sub-central governments and related agencies. This ensures that the operator is effectively compensated for services rendered during the period of the concession period. It requires the government or granting public agency to recognize assets and liabilities in their financial statements, when the following are met:

- The government or granting public agency controls or regulates the services to be provided, the target beneficiaries or the price; and

- If the grantor controls through ownership, beneficial entitlement or otherwise, a significant residual interest in the asset at the end of the arrangement.

In the schema of Chart 2, this would involve elements in the areas $\mathrm{R}$ and $\mathrm{E}$. This avoids the situation where neither the public or private partner recognizes the asset/liability at the end of the period. Of course, as has been seen in Ireland and Spain recently (and with Mexican road in the early 1990s), even if there are no explicit guarantees by the federal or state governments and there is sufficient

\footnotetext{
${ }^{11}$ See IASB (2011), IPSAS 32. This standard is also likely to affect the guidelines of Eurostat that are not so tightly defined.
} 
pressure on the banking system, it is likely that the state will assume a significant portion of the liabilities.

The implications are that (1) the annual budgets for each level of government must be cast in a medium-term framework; (2) it is essential to undertake a full and careful evaluation of assets and liabilities and associated accounting and reporting of risks with a sufficiently long time horizon (using international standards, such as the GFSM2001); and (3) it is always important to be able to track the cash, and the design of national and subnational TSAs becomes critical.

\section{Following the cash-TSAs and transparency}

One of the most important common features of budget systems across the world, whether of the "traditional" line item variety (as in most developing countries-and Germany), or of the more modern flexible systems, that rely on spending agency accountability (as in Scandinavia), is a treasury single account (TSA). This institutional feature has been recommended by the IMF in a large number of countries as part of its Technical Assistance and Capacity Development. Despite some successes, as in PR China, establishing a TSA has proved elusive in countries from Mexico (the only OECD country without a TSA a the time of writing) to Pakistan.

The difficulty in establishing a TSA lies primarily in vested interests, both political as well as bureaucratic (for details, see Ahmad and Jensen, forthcoming). Often at the national level, there is spending by security agencies, donors, and other political centers of power- and the key question is whether these can be included within the TSA?

The same issues arise with respect to sub-national entities. Should local governments have their own TSAs? Should they use a central TSA? What are the problems posed by donors, both multilateral (such as the World Bank) or bilateral agencies that may not trust the local governments to use their funds efficiently or without significant leakages?

Some countries do not have sufficiently large subnational entities for it to be efficient to establish local TSAs. ${ }^{12}$ In some cases, the IMF has recommended that the local governments use the central TSA. While this may be desirable in principle, the practice can be a severe problem. Suddenly, local governments face a closure of their bank accounts, and do not know where the money goes and their balances.

12 The Chinese provinces are larger than most countries and have their own TSAs, nested and linked with the Central TSA in Beijing. This is a very interesting model and could usefully be examined in the larger multi-level countries-e.g., other members of the BRICS and countries of similar size, such as Indonesia or Pakistan. 
And in order to issue payment orders, they have to send emissaries to the central Ministry of Finance and petition the Treasury to release funds. This adds to the complexity of the local budget process and could endanger the decentralization process.

What are the problems with donors-seen e.g., in a range of countries? The insistence to keep separate bank accounts for their spending poses the risk of parallel budget processes, and makes it hard for either local or central governments to get a grip on total spending. Besides obfuscating the budget process, it reduces the accountability for achieving results.

A solution is shown in Chart 3-with a modification of the TSA principle often used for "independent" bodies, including security agencies-the principle of establishing correspondent accounts (CA) within a TSA. Thus CA1 would be the account of local government 1; and CA2 that for a bilateral agency, say the GIZ that might want to keep its operations separate, or even a security agency at the national level.

If there is a GFMIS, then the operations of the CA become the responsibility of the local government or the bilateral/security agency. They could issue payment orders to the extent of their resources in each account. Without a GFMIS, it may be necessary to establish a series of zero-balance accounts in commercial banks, again subject to the resources in the respective accounts. This cuts through the bureaucracy, and yet all levels of government have full information on who spends what and when. Thus, both cash management (best managed at the central level in most cases), and information flows are facilitated.

This small example illustrates that often the first best may makes matters worse, if implemented without thinking in inappropriate conditions. It is often necessary to work through why there is no TSA in a particular context, and then try and address the issues on a case-by-case basis. This involves work to understand the political economy constraints in each case. 
Chart 3

\section{TSA with donors/local government}

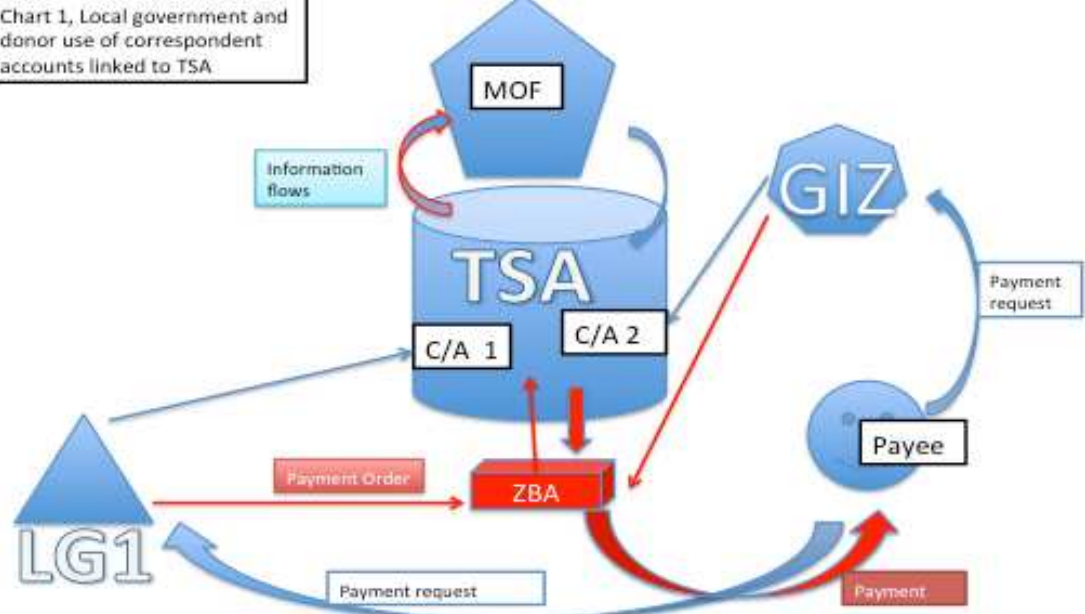




\section{Incentive Structures and Design and Management of Transfer Systems}

All the carefully designed and implemented incentive structures described above could be negated if a transfer system were to cover all deficits and debts without any constraints. The creation of a level playing field through a system of equalization transfers is critical-this should enable all subnational governments to provide similar levels of services at similar levels of tax effort.

However, for investment needs and infrastructure gaps to maximize the growth potential, it would be useful to begin to create the preconditions for performancebased transfers. This would ensure that the investments produce results and are managed efficiently. Such transfers could also be used to promote central government objectives, such as social protection for the marginalized and most vulnerable. However, care needs to be taken should the transfers be implemented in areas of local government jurisdiction, as this could lead to a diversion of resources and additional "game play."

\section{Earmarked transfers}

Many countries try to achieve central government objectives in an increasingly decentralized context through a system of earmarked transfers. The biggest drawback of excessive earmarking is that it overrides local preferences, and is inimical to the basic philosophy underlying the decentralized processes-i.e., to generate accountability for local responsibilities. Moreover, a big constraint faced by countries with weak PFM systems, and poor information on who spends what, is that it is hard to ensure that the funds are not diverted to other heads that may be more important for local officials-or just stolen.

As described in Ahmad (2009), it may be possible to offset some of the PFM disadvantages by inducing competition among recipient jurisdictions, using simple performance criteria. The basic idea is that a medium-term budget framework is put in place, and the transfers in period $t+2$ are made conditional on achieving targets set for period $t+1$.

Thus, if growth and employment generation is an objective, and is not achieved by additional transfers given to the metropolitan areas, it may be useful to reconsider the strategy in the coming period. Also the relationships between the metropolitan administration and the decentralized subordinate municipalities would clearly need to be clarified. Eventually, when the PFM systems are strong enough, and the court 
systems function efficiently, one could consider "contract" based transfers (Spahn, 2006).

\section{Equalization transfers}

\section{Design}

Under a modern system of "equalization" the objective could be to "assign transfers so that subnational governments could provide equal standards of service at equal levels of tax effort". This is the modern mechanism that has been used across States in Australia, provinces in China, and municipalities and districts in Denmark, Hungary. A more restricted arrangement based on equalizing revenue capacities only is used in Canada-but a replication of this to other countries assume that local governments have some control over local revenue bases (either through control over rates or through elements involved in the tax administration.

Very simply, the equalization framework would be based on "standardized" factors. This ensures that local governments would not be able to influence the magnitude of the transfer by their actions or lack of actions (see Ahmad and Searle, 2006, for a description of alternative models).

The standardized transfers thus become more or less "lump sum" and do not distort incentives at the local level. The standardized spending responsibilities would address differential costs of provision for services assigned to them, with higher costs in remotely populated areas, as well as densely populated urban districts. Similarly, the own-revenue potential would be based on standardized revenue (spatial distribution of bases, assuming average rates), and the fact that a local government chooses not to exploit a revenue base would not lead to a higher grant. Thus, there would be an incentive to better utilize assigned revenue bases.

The equalization framework in Indonesia started out in 2001 on the basis of standardized factors, but these were changed into actual spending and transfersconverting it into an estimate of the actual gap. This completely changed the incentive structure, as the deficit came under the control of local governments and generated a trend towards inefficient expansion of spending, especially on personnel and benefits.

It is important to avoid complexity in the design of equalization frameworks. The Australian model has been criticized as having become so complicated that it becomes hard to judge the economic outcomes and implications (see Shah, this volume). However, there has been a conscious attempt in the Commonwealth Grants Commission to simplify models and factors used to estimate disabilities. The Chinese application of the Australian equalization framework also used very simple 
factors, such as relevant population for the functions being equalized. Clearly, population, which is also used as the basis for simple transfers (which makes it a very political variable), is still important as a factor for equalization. But using it in a standardized manner to evaluate relative costs or needs diffuses the perceived concerns with the population variable-as the simplified mechanism of total population could be "disequalizing" in the sense that more transfers might be provided to the better-off regions.

Overall, a modern equalization framework should shift the focus from "entitlements" to a political focus on service delivery by local governments. This helps with local oversight and could help also generate "yardstick competition". In the following, some common formulations for general-purpose transfers are discussed.

\section{Formula-based General Purpose Transfers ${ }^{13}$}

There are five types of formulas currently used around the world for general transfers.

\section{a. Transfers based on equal per capita allocations}

This is the simplest system for allocation of grants requiring only information on population. It is used in a number of countries, such as Germany for the allocation of a share of VAT and Canada for the allocation of the block grant for health and social services. It assumes that population is a suitable indicator of local expenditure needs. It also has minimal equity content since it gives the same per capita amount to poor and rich areas, although it does not consider revenues. The formula would be as follows:

$$
T R_{i}=\left(P_{i} / P\right) \times T R
$$

where $T R$ is the transfer; $P$ is population; $i$ stands for local unit $i$. Variables without $i$ refer to the country total.

Countries at an early stage in their intergovernmental arrangements, such as Cameroon, have used this formulation. While the population figures are relatively robust in principle, once the transfers are linked to this factor, there is hesitancy in updating the figures-so that there is not much of a shift in resource allocation patterns. The figure has thus become "politicized." Moreover, by definition, more resources flow to where the population density is greatest-and these tend to be the richest areas with the best facilities. This potentially introduces a bias against the less well to do areas, or where there are higher costs of provision of services (typically the poorer areas).

13 This section is based on Ahmad and Brosio (2010). 


\section{b. Formulae based on general indicators of expenditure needs}

These formulae are very popular and derive from the previous one by adding other indicators of needs such as poverty incidence, area, population density, infant mortality, and (inverse) of GDP. The indicators are not related to distinct expenditure responsibilities assigned to local governments, but to their total expenditure.

An illustration of a simple formula follows, with three equally weighted indicators: geographic area and the number of poor persons, in addition to population:

$$
T R_{i}=P_{i} / P \times 1 / 3 T R+P_{0 v} / P o v \times 1 / 3 T R+A_{i} / A \times 1 / 3 T R,
$$

where in addition to previous symbols Pov is the number of poor persons and $A$ is area $\left(\mathrm{km}^{2}\right)$.

The difficulty with this formulation is that it is hard to link the factors with reasons for spending or transfers. Indeed, perverse incentives can be created, such as the need to maximize the number of poor in order to attract the highest amount of transfers. This could encourage perverse decision-making.

\section{c. Formulae based on specific indicators of expenditure needs}

These formulae are more complex since they use distinct indicators of need for each local expenditure responsibility. These are a considerable improvement over the general needs formulations, but require more information that may be subject to obfuscation if not managed in a transparent way.

An example is provided by South Africa, where the general purpose transfer to the provinces is allocated according to a system that has six components: (i) an education component, representing 51 percent of the total transfer allocated according to population in school age and to school enrolment; (ii) a health component, representing 26 percent of the total transfer allocated according to population with and without medical aid; (iii) a basic component, representing 14 percent of the total transfer allocated according to population; (iv) a poverty component, representing 3 percent of the total transfer allocated according to the number of poor persons (quintiles 1 and 2); ( $\mathrm{v}$ ) an economic activity component, representing 1 percent of the total transfer allocated according to GDP; and (vi) an institutional component, representing the remaining 5 percent equally distributed as a lump sum among provinces.

The formula for the education component would be the following: 


$$
E T R_{i}=S A P_{i} / S A P \times 0.5 E T R+E n_{i} / E n \times 0.5 E T R
$$

where, in addition to previous symbols, ETR is the education component of the transfer; $S A P$ is school-age population; and $E n$ is the number of pupils enrolled in schools. Similar formulae would apply to other expenditure functions.

One has to be careful with the use of spending information for various functions. If actual numbers are used, these are generally under the control of the subnational governments. Thus, higher spending would attract higher transfers, and the disincentive effects are obvious-as in the Indonesian case. A general principle is to avoid using factors under the direct control of subnational governments. This would minimize the incentives for "game-play" that are inherent in this class of formulae and transfer design.

\section{d. Formulae based only on fiscal capacity}

In this case, the transfer does not take account of expenditure needs, but only differences in fiscal capacity. An example is provided by the Canadian system of general-purpose transfers to provinces based on differences in tax capacity. This formulation assumes, correspondingly, that each province has the same per capita expenditure needs. It has to be noted that the Canadian provinces are very large in terms of area, which reduces the variance in average expenditure needs. Furthermore, the general-purpose transfers to provinces are supplemented with specific transfers based on needs-such as for health care or education.

A transfer-design formula based on revenue capacity would be as follows:

$$
T R_{i}=t \times\left(B / P-B_{i} / P_{i}\right) \times P_{i}
$$

where, in addition to the previous symbols, $B$ is the effective tax base (not the assessed tax base, but the base that potentially can be assessed; and $t$ is the average effective tax rate on the concerned tax base).

Since $B / P-B_{i} / P_{i}$ measures the difference between the per capita national average tax base and that of region $i$, the formula brings the fiscal capacity of those subnational governments that are below the national average up to the national average, i.e., it provides 100 percent equalization with reference to the national average. Equalization can obviously be less intense.

Note that the use of the potential rather than actual addresses the problem of incentives. If actual revenues are used for the calculation of transfers, it would induce subnational governments to reduce their tax effort.

\section{d. Formulae that consider both expenditure needs and fiscal capacity}


These formulas provide the most general approach to equalization systems, and rely not only on needs but also the ability to provide for these through own-source revenues. Thus, this formulation is closest in spirit to a full accountability for assigned functions with the closest linkage between functions and financing. Standardized expenditure needs are estimated for each assigned function and linked to standardized revenue capacity. The resulting equalization transfer is thus close to being "lump-sum" as possible in that local decisions on the level of spending are determined by local preferences, as shown in the following formula:

$$
T R_{i}=? N_{i j}-F C_{k}
$$

where, in addition to previous symbols, $N_{i j}$ is the standardized expenditure need for function $j$ in jurisdiction $i . F C$ is standardized fiscal capacity. As the transfer is "lumpsum", the jurisdiction could choose to spend more or less by adjusting ownrevenues than would be implied by the transfer, without affecting the magnitude of the transfer.

Such formulae are used in an increasing number of countries such as Australia, China, Denmark, Japan, Korea, and the United Kingdom. They can be complex and, as in the Australian case, require a considerable amount of information. The recent reforms in Australia to simplify the estimation of cost functions and factors, is a step towards making the system much more intuitively apparent, moving towards the simpler systems adopted in countries with data constraints, as in China. Thus, if properly formulated and implemented, full equalization systems can be both efficient and equitable.

\section{Management of Transfers: a new Grants Commission}

The options to implement an equalization grants system vary from the establishment of an independent Grants' Commission to entrusting the function to the Ministry of Finance or other line agency, such as the Ministry of Home Affairs or Local Governments, or both Ministries (as in Indonesia). Table 3 presents some international experiences.

An independent Grants' Commission could be established to determine the relativities for making equalization transfers, in coordination with the local governments. It does not make payments directly, which are routed through the Treasury, but establishes the basis and monitors and collects the information needed to make the system work. In countries such as Australia, the Grants Commission is an independent agency with representation by the subnational governments.

In countries such as Mexico or China, the Ministry of Finance manages the Grants function. Often there is a separate section within the Treasury/MOF to administer this function. 
Table 3 Institutional arrangements for Equalization Transfers

\begin{tabular}{|c|c|c|c|c|c|c|c|}
\hline & \multirow{2}{*}{$\begin{array}{l}\text { Is there a } \\
\text { Separate } \\
\text { Agency to } \\
\text { Advise on } \\
\text { Grants } \\
\text { Distribution? }\end{array}$} & \multirow{2}{*}{$\begin{array}{l}\text { Ministry } \\
\text { administer- } \\
\text { ing Untied } \\
\text { Grant } \\
\text { Distribution }\end{array}$} & \multirow{2}{*}{$\begin{array}{l}\text { Is Local } \\
\text { Government } \\
\text { Involved in } \\
\text { Grant } \\
\text { Decisions? }\end{array}$} & \multicolumn{4}{|c|}{ Where a Separate Agency Operates } \\
\hline & & & & $\begin{array}{l}\text { Is the } \\
\text { agency } \\
\text { permanent } \\
\text { ? }\end{array}$ & $\begin{array}{l}\text { Does it } \\
\text { operate } \\
\text { under the } \\
\text { Constitution } \\
\text { or a law? }\end{array}$ & $\begin{array}{l}\text { What is its } \\
\text { range of } \\
\text { functions? }\end{array}$ & $\begin{array}{l}\text { What is the size of } \\
\text { the agency? }\end{array}$ \\
\hline Australia & Yes & & Yes & Yes & Law & Narrow & Small \\
\hline Canada & & $\mathrm{MoF}$ & Yes & & & & \\
\hline China & & MoF & $?$ & & & & \\
\hline Denmark & & MoF & Yes & & & & \\
\hline Ghana & Yes & & No & Yes & Constitution & Narrow & Very small \\
\hline Ethiopia & & $\begin{array}{l}\text { House of } \\
\text { Federation } \\
\text { and MoF }\end{array}$ & Yes & & & & \\
\hline India & Yes & & Yes & No & Constitution & Narrow & Small \\
\hline Japan & & MoLG & Yes & & & & \\
\hline $\begin{array}{l}\text { South } \\
\text { Africa }\end{array}$ & Yes & $\begin{array}{l}\text { MoF and } \\
\text { MoLG }\end{array}$ & Yes & Yes & Constitution & Wide & Large \\
\hline $\begin{array}{l}\text { South } \\
\text { Korea }\end{array}$ & & MoLG & Yes & & & & \\
\hline Sudan & Yes & MoF & Yes & Yes & Constitution & Wide & Large \\
\hline Uganda & Yes & & Yes & Yes & Constitution & Wide & Small \\
\hline
\end{tabular}

Note: MoLG = Ministry of Local Government; MoF = Ministry of Finance.

Source: Searle 2010 in Ahmad and Al Faris, Fiscal Reforms in the GCC, Edward Elgar. 


\section{Performance based transfers}

There is an expectation that results-based intergovernmental transfers could lead to positive infrastructure and service-delivery outcomes, with improved allocative efficiency, better implementation, and lower costs. ${ }^{14}$ Such grants have been increasingly stressed by the international agencies, including the ADB and the World Bank.

Performance-based transfers have to be carefully designed and managed, especially if implemented in the sphere of subnational government competence. If inadequate attention is paid to the factors that could be attributed to local government actions, such transfers could lead to a diversion of ownresources to less productive activities, and also reduce accountability. The cycle from objectives to outcomes has to be carefully specified, and exogenous factors need to be taken into account (see Chart 4).

The technical efficiency process is the regular budget process that links the allocation of funds through to the funds actually spent, as well as outcomes. These would be normally tracked through with the help of a GFMIS, preferably on a standardized basis for all subnational and central/federal governments. The IADB has assisted a number of Latin American countries, including Bolivia, with such subnational GFMISs, although with insufficient attention to the Chart of Accounts and tracking spending on a GFSM2001 compatible basis. In addition a linkage has to be made between the outcomes and the service objectives, and there is a degree of subjectivity in determining the exogenous factors that might have played a part.

If the performance-based transfers are based on complex input criteria, or detailed standards that cannot be monitored or enforced, the conditionality becomes irrelevant. Similarly, a focus on outputs rather than outcomes may lead to unintended or perverse incentives. Nonetheless, even in situations where information on budget spending is partial or subject to delays, physical outcomes may be relatively simple to identify quickly and accurately-this could be particularly useful for infrastructure projects. These could be measured and additional funding in future rounds could be made conditional on these outcome indicators (Ahmad and Martinéz, 2010). Care has to be taken to ensure that the positive incentives from a performance-based system are not negated by other badly designed transfers, for instance based on gap-filling or other distortive criteria.

Chart 4

${ }^{14}$ UNCDF, 2010. “Performance-based Grant Systems: Concept and International Experience." 


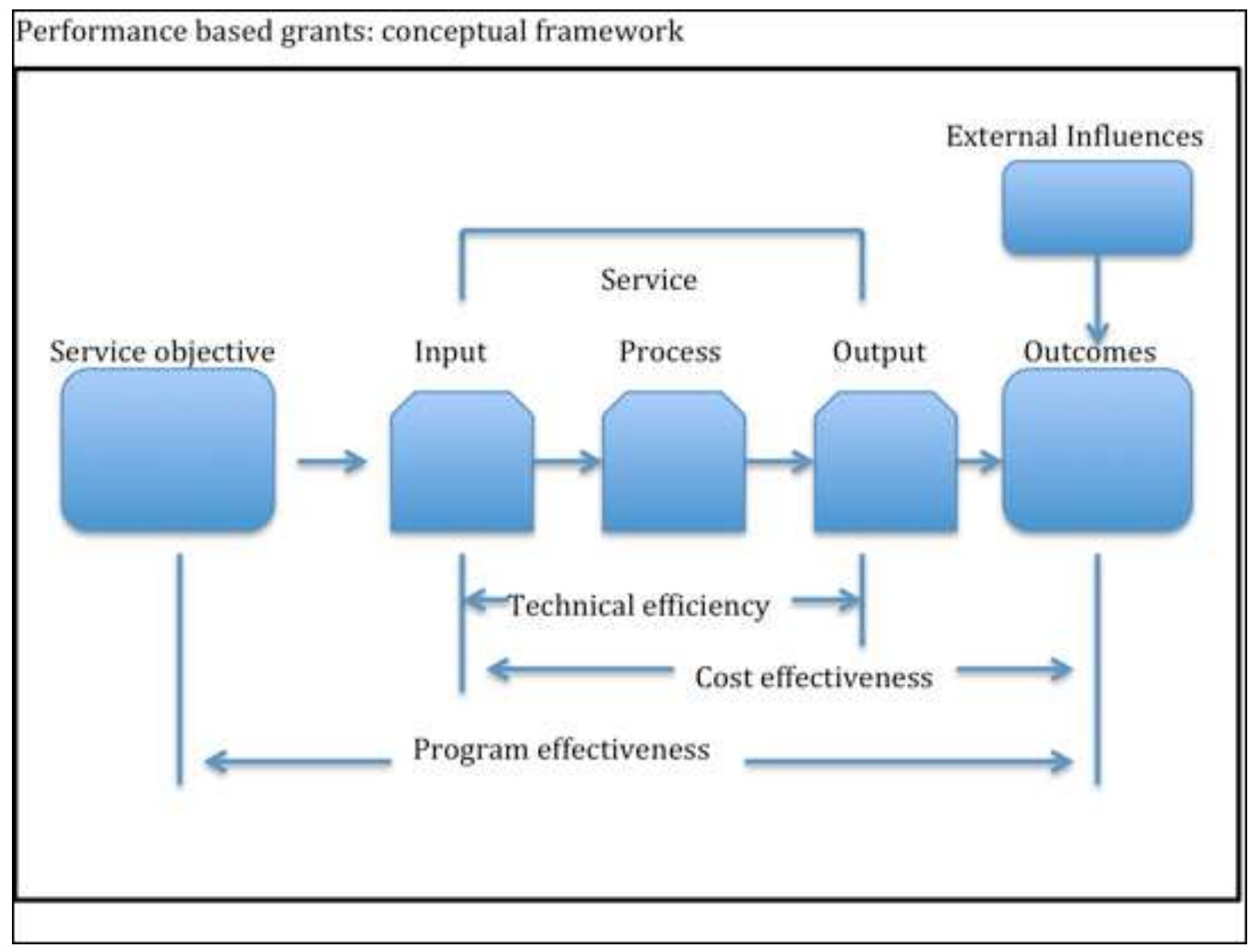

A performance-based system should supplement local government actions and responsibility, such as through meeting infrastructure gaps that are hard for local governments to address, and which can be easily monitored. In the longer run, more effective and standardized PFM systems are essential for information flows to improve efficiency and accountability. Similarly, incentive structures depend on whether or not sub-national entities have access to own-source revenues and are subject to hard budget constraints. While, this mutual interdependency will take many years to work through, countries such as Indonesia could introduce simple performance-based grants in specific sectors, or discrete areas that will improve outcomes. 


\section{References:}

Ahmad, Ehtisham, James Rydge and Nicholas Stern, 2013, "Structural change drives tax reforms drives structural change," LSE, presented at the China Development Forum.

Ahmad, E., M. Best and C. Pöschl (2013), "A tax reform agenda in the presence of informality-the case of Mexico," LSE Discussion Paper, January 2013.

Ahmad, E. and M. Best (2012), "Financing social policy in the presence of informality," LSE_ARC Working Paper April 2012.

Ahmad E. and G. Brosio (2006), Handbook of Fiscal Federalism, Edward Elgar.

Ahmad E., and G. Brosio (2009), Does Decentralization Enhance Service Delivery and Poverty Reduction? Edward Elgar,

Ahmad E., and G. Brosio (2009a), "Political economy of multi-level tax assignments in Latin America: earmarked revenue versus tax autonomy," National Tax Journal, 2009.

Ahmad, E., G. Brosio and V. Tanzi (2008), "Local service provision in selected countries: do decentralized operations work better," in G. Ingram and Y-H. Hong, Fiscal Decentralization and Land Policies, Lincoln Institute.

Ahmad E., and G. Brosio (2011), "Intergovernmental fiscal relations and transfer design in Iraq," UNHABITAT.

Ahmad, E. and M. García-Escribano (2011), "Constraints to Effective Fiscal Decentralization in Peru" (with Mercedes García-Escribano), in Jorge Martinez-Vaszquez and François Vaillancourt, (eds), Obstacles to Decentralization: Lessons from Selected Countries, Edward Elgar.

Ahmad E., and L. Martinéz (2010), "Intertemporal competition and aid," Economics and Politics.

Ahmad, E. and B. Searle (2006), "On the implementation of transfers to subnational governments," In Ahmad and Brosio (2006).

Ambrosiano, F. and M. Bordignon (2006), "Normative versus positive theories of revenue assignments," in Ahmad and Brosio (2006). 
Besley, T. and A. Case (1995), "Incumbent behavior, vote-seeking, tax-setting, and yardstick competition," American Economic Review, 85, 25-45.

Dafflon, B. (2006), "The assignment of functions to decentralized government: from theory to practice," in Ahmad and Brosio (2006).

Danau, Daniel and Annalisa Vinella (2012), "Public-private contracting under limited commitment," SIEP Annual Conference, 2012, Pavia.

European Union: The Maastricht Treaty,

http://eur-lex.europa.eu/en/treaties/dat/12002E/pdf/12002E_EN.pdf.

Gadenne, Lucie (2012), "Tax me, but spend wisely-the political economy of taxes: evidence from Brazil," Mimeo, University of London.

G30, (2013)Long term finance and economic growth, Working Group on Long Term Finance, Washington DC.

House of Lords, 2010, Private Finance Projects and Off-balance sheet Debt, First Report of Session 2009-10, Vols I and II, Report and Evidence, HL Paper 63, III.

IMF, Government Financial Statistics Manual 2001 (GFSM2001), Washington DC.

Mexican Ministry of Finance and Public Credit and IMF, FAD 2007 Mexico: Options for the Reform and Strengthening of Intergovernmental Fiscal Relations, (Team led by E. Ahmad with M. García-Escribano, R. Blavy, (IMF) J. Draaisma (World Bank), J.A. González Anaya (Vice-Minister, SHCP), E. Revilla (DG SHCP), C. Berthaud, G. Brosio, I. Garrido, B. Lockwood (Consultants), March 2007).

North, D. (1990), Institutions, Institutional Change and Economic Performance, Cambridge University Press.

Salmon, P. (1987). "Decentralisation as an incentive scheme", Oxford Review of Economic Policy 3(2), 24-43.

Salmon, Pierre (2006). "Horizontal competition among governments", in: Ehtisham Ahmad and Giorgio Brosio (eds), Handbook of Fiscal Federalism, Cheltenham: Edward Elgar 2006.

Searle , Bob (2010), in Ehtisham Ahmad and Abdelrazak Al Faris, Fiscal Reforms in the GCC, 2010, Edward Elgar.

Spahn, P.B. (2006), “Contract federalism,” in Ahmad and Brosio (2006). 
Ter-Minassian, T (ed., 1997), Fiscal Federalism in Theory and Practice, IMF, Washington DC.

UNCDF, (2010). “Performance-based Grant Systems: Concept and International Experiences.

Ter-Minassian, T., (forthcoming), "Promoting responsible and sustainable fiscal decentralization," in E. Ahmad and G. Brosio, Handbook of Fiscal Federalism II. 